\title{
Effect of Post-Heating Temperature on Efficiency of Dye-Sensitized Solar Cell with ZnO:Al Thin Films Prepared by Sol-Gel Spin Coating
}

\author{
Nurdin Siregar, ${ }^{*}$ Motlan, and Jonny Haratua Pangabean \\ Department of Physics, Universitas Negeri Medan, Willem Iskandar Road Pasar V \\ Medan Estate, Medan 20221, Indonesia \\ *Corresponding author: siregarnurdin@unimed.ac.id
}

Published online: 25 August 2021

To cite this article: Siregar, N., Motlan, \& Pangabean, J. H. (2021). Effect of postheating temperature on efficiency of dye-sensitized solar cell with $\mathrm{ZnO}: \mathrm{Al}$ thin films prepared by sol-gel spin coating. J. Phys. Sci., 32(2), 57-70. https://doi.org/10.21315/ jps2021.32.2.5

To link to this article: https://doi.org/10.21315/jps2021.32.2.5

\begin{abstract}
Dye-sensitized solar cell (DSSC) has a great potential to convert solar light into electricity. In this article, a prototype of DSSC had been successfully fabricated using $\mathrm{ZnO}$ :Al thin film and dye from red dragon fruit as a working electrode. $\mathrm{ZnO}:$ Al thin films were prepared by a sol-gel spin coating method with variation of post-heating temperatures. The XRD result confirms that all $\mathrm{ZnO}$ :Al thin films have a hexagonal structure with crystal sizes of $16 \mathrm{~nm}$ to $41 \mathrm{~nm}$. SEM analysis showed the nanoparticles with particle size of $30 \mathrm{~nm}$ to $80 \mathrm{~nm}$. The bandgap ranges from $3.16 \mathrm{eV}$ to $3.40 \mathrm{eV}$. The EIS analysis reveals that charge transfer resistance greatly decreases with the rise of temperature. The efficiency of DSSC gradually improved with increasing the post-heating temperature. $\mathrm{ZnO}: \mathrm{Al}$ with a post-heating temperature of $600^{\circ} \mathrm{C}$ had the highest efficiency of $0.398 \%$.
\end{abstract}

Keywords: dye sensitised solar cell, $\mathrm{ZnO}$ :Al thin films, sol-gel spin coating, red dragon fruit extract

\section{INTRODUCTION}

Dye-sensitized solar cell (DSSC) is one of the solar cell types that originally invented by Gratzel in 1991. ${ }^{1}$ The fabrication of DSSC is low cost and environmentally friendly. It consists of several components, namely, semiconductor oxide, dye, counter electrode and electrolyte. ${ }^{2}$ The engineering of $\mathrm{ZnO}$ semiconductor for the DSSC working electrode is promising because it has an energy bandgap of $3.37 \mathrm{eV}$ and a binding energy of $60 \mathrm{meV}$ which 
allows direct absorption of UV radiation. ${ }^{3} \mathrm{ZnO}$ thin film has poor electrical characteristic like having a low conductivity value of $6.24 \times 10^{-7}(\Omega . \mathrm{cm}) \mathrm{s}^{-1}{ }^{4}$ To enhance its physical, optical and electrical properties, it is often doped with extrinsic dopant from group IIIA such as $\mathrm{B}, \mathrm{Al}$ and $\mathrm{Ga}$ as foreign element doped into the $\mathrm{ZnO}$ structure. ${ }^{5}$ Aluminium (Al) is chosen as a doping agent because it can increase the electrical conductivity of $\mathrm{ZnO}$ thin films to an order of $10^{5} \Omega . \mathrm{cm} .{ }^{6}$ There are several techniques to fabricate thin film such as molecular beam epitaxy, radio frequency (RF) magnetron sputtering, pulsed laser deposition, spray pyrolysis, physical vapour deposition, and sol-gel spin coating. ${ }^{7-12}$ A sol-gel spin coating method has several advantages, including not using a high vacuum space, low cost, homogeneous composition, controllable layer thickness and great microstructure. ${ }^{13}$

Islam et al. studied $\mathrm{Al}$-doped $\mathrm{ZnO}$ and they found that the energy bandgap value was affected by the doping concentrations. ${ }^{14}$ The crystal size, transmittance and energy bandgap increase with the increasing of heating temperature. ${ }^{15}$ The efficiency of DSSC is not only influenced by Al concentration but also annealing temperature. ${ }^{16,17}$ Recently, Bekele et al. had successfully utilised the root extract of Kniphofia schemperi as the natural dye for DSSC. ${ }^{18}$ Based on these considerations, it is interested to conduct research on DSSC using Al-doped $\mathrm{ZnO}$ thin film prepared by a sol-gel spin coating method with variation of post-heating temperatures and extract red dragon fruit as the natural dye sensitized.

\section{EXPERIMENTAL}

\subsection{Synthesis of ZnO:Al Thin Films}

ZnO:Al thin film was synthesised using a sol-gel spin coating method. ${ }^{19}$ Typically, $4 \mathrm{~g}$ of zinc acetate dihydrate and Al $1.0 \%$ was dissolved into $20 \mathrm{ml}$ isopropanol and then stirred with a magnetic stirrer. After $10 \mathrm{~min}, 1.72 \mathrm{ml}$ diethanolamine (DEA) was added slowly as a stabiliser agent. The gel solution was then dropped onto indium tin oxide (ITO) glass substrate and then rotated by a spin coating with a speed of 5,000 rpm. Finally, the sample was heated with temperature of $250^{\circ} \mathrm{C}$ for 5 min to remove the excess liquid. Finally, the sample was annealed in an electric furnace with temperatures of $400^{\circ} \mathrm{C}, 450^{\circ} \mathrm{C}, 500^{\circ} \mathrm{C}$, $550^{\circ} \mathrm{C}$ and $600^{\circ} \mathrm{C}$ for $5 \mathrm{~h}$. 


\subsection{Characterisations of $\mathrm{ZnO}$ :Al Thin Films}

The crystal properties of $\mathrm{ZnO}: \mathrm{Al}$ thin films were evaluated using X-ray diffractometer (LabX XRD-6100, Shimadzu) with $\mathrm{Cu} \mathrm{K}_{a}$ radiation (40 kV, $30 \mathrm{~mA}$ ) of wavelength $1.54 \AA$. A field emission-scanning electron microscopy (FE-SEM, JEOL 6500) with accelerating voltage of $15 \mathrm{kV}$ and working distance of $10 \mathrm{~mm}$ was used to observe the surface morphology of the thin films. The optical properties of thin films were further investigated using UV-visible (UV-vis) spectrometer with both transmission and absorbance modes from the wavelength of $300 \mathrm{~nm}$ to $700 \mathrm{~nm}$. Electrochemical impedance spectroscopy was performed using Biologic SP-300 Potentiostat. The characterisations were conducted in Indonesia and Taiwan.

\subsection{Preparation of Dye Sensitizer}

The extract of dye sensitizer was done by cutting red dragon fruit into small pieces and then put it into a beaker glass. After that, the red dragon fruit is crushed by mortar until smooth. Extraction was done by adding ethanol and then soaked for $24 \mathrm{~h}$ in a dark place. ${ }^{18}$ Finally, the extract was filtered using filter paper and stored in a under dark place.

\subsection{Fabrication of DSSC}

The DSSC was fabricated by attaching a platinum counter electrode to a $\mathrm{ZnO}$ : Al thin film coated with dye from red dragon fruit which acted as a working electrode with a layer of separating surlyn. Sticking of surlyn was conducted by pressing the working electrode and the counter electrode under heating with temperature of $70^{\circ} \mathrm{C}$ to $80^{\circ} \mathrm{C}$ to stick them perfectly. ${ }^{20}$ The electrolyte was injected through a small hole found in the counter electrode.

\subsection{Efficiency Measurement}

Electrical testing was carried out by assembling an electrical circuit between the DSSC and digital multimeters as shown in Figure $1 .{ }^{21}$ This test is based on the beam lighting method to determine the performance and efficiency of the cells obtained when the solar cell is exposed to light with a certain intensity at the top anode. DSSC outputs are open-circuit voltage $\left(\mathrm{V}_{\mathrm{oc}}\right)$ and short-circuit current $\left(\mathrm{I}_{\mathrm{sc}}\right)$ DSSC. Then, the fill factor (FF) and the DSSC efficiency $(\eta)$ were calculated. 


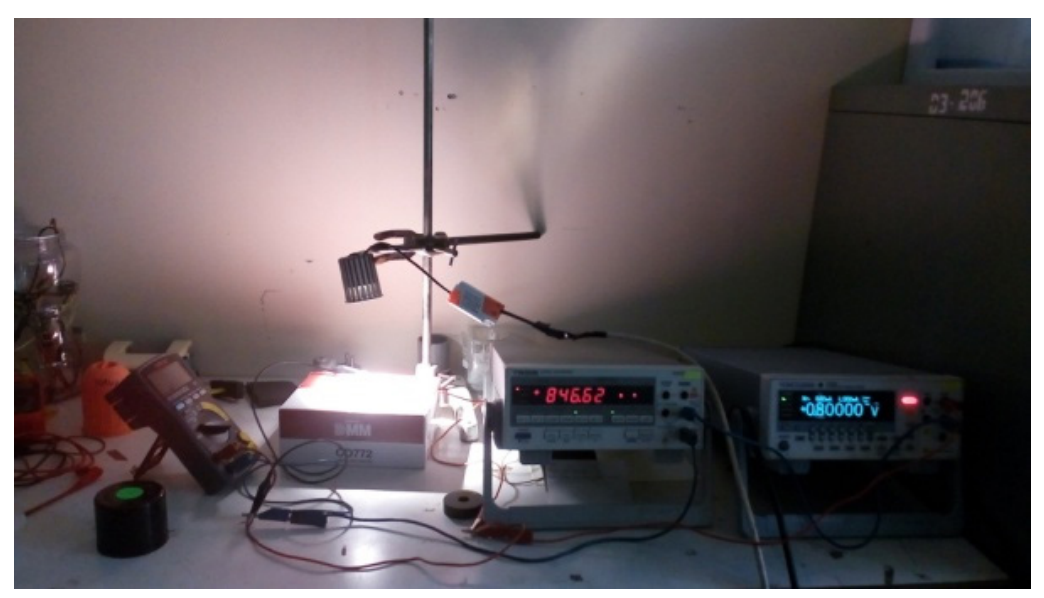

Figure 1: Measurement efficiency of DSSC.

\section{RESULTS AND DISCUSSION}

\subsection{Crystal Structure of ZnO:Al Thin Film}

The diffraction pattern of $\mathrm{ZnO}: \mathrm{Al}$ thin film with variation of post-heating temperatures is shown in Figure 2. The result confirm that all samples have the same crystal structure of hexagonal wurtzite according to the database with JCPDF No. \#36-1451. ${ }^{22}$ The XRD pattern shows three peaks with (100), (002) and (101) planes where a (101) plane has the highest intensity indicating the preferred crystal growth.

Crystallite size of the samples with variation post-heating temperatures are calculated using the Scherrer's equation. ${ }^{23}$

$$
\mathrm{D}=\frac{0.9 \lambda}{\beta \cos \theta}
$$

Where, $\mathrm{D}=$ crystallite size, $\lambda$ = wavelength, $\beta=\mathrm{FWHM}$ (full width half maximum), $\theta=$ diffraction angle.

Table 1 shows the crystal size increases from $16 \mathrm{~nm}$ to $41 \mathrm{~nm}$ along with an increase in post-heating temperature from $400^{\circ} \mathrm{C}$ to $550^{\circ} \mathrm{C}$. This was because increasing heating temperature will make compaction increase and grow large granule due to the incorporation of small grains. ${ }^{24}$ When the post-heating temperature was increased to $600^{\circ} \mathrm{C}$, the crystallite size decreased to $34 \mathrm{~nm}$ due to aluminium as dopant block the grain boundaries. ${ }^{25}$ 


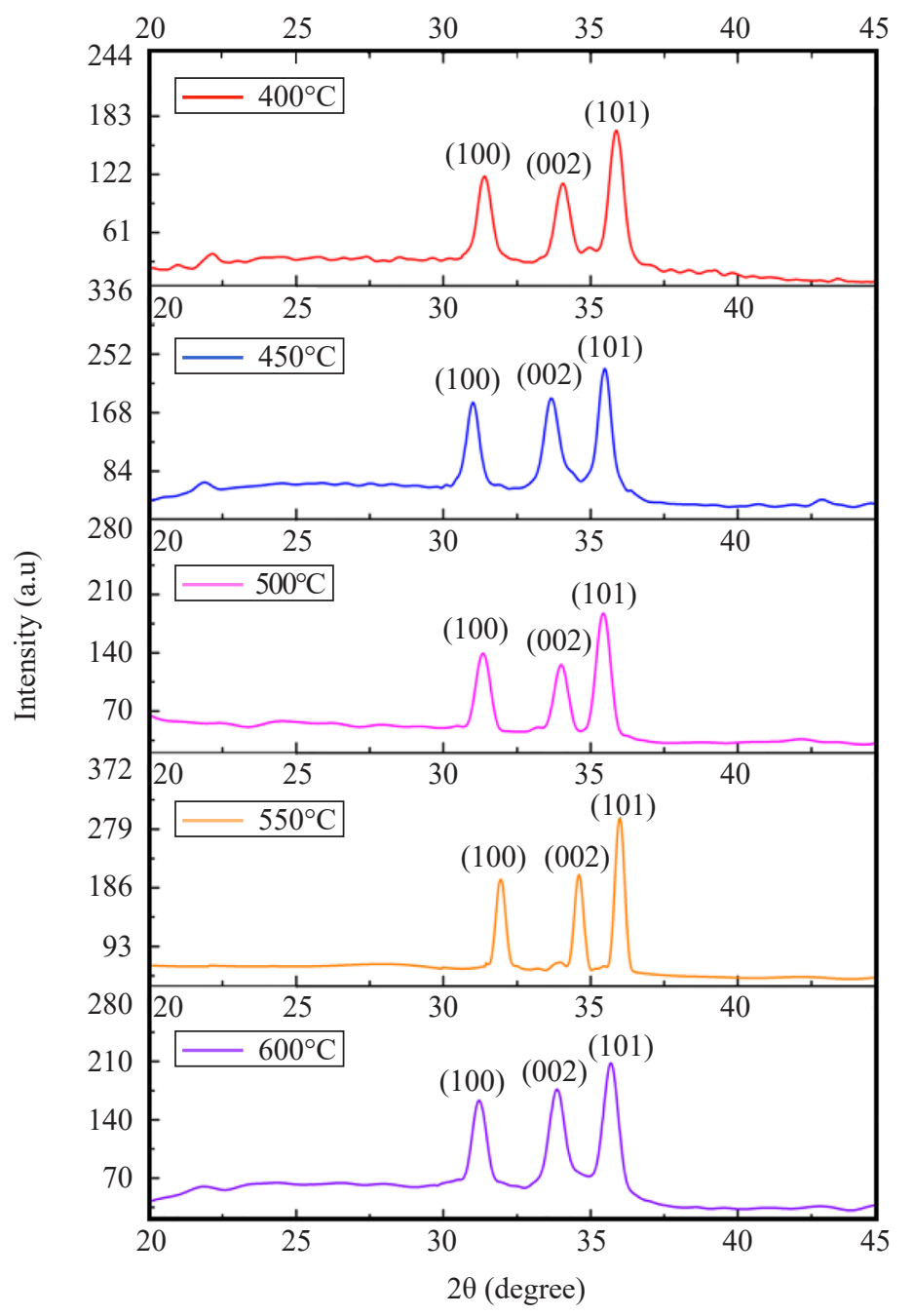

Figure 2: X-ray diffraction spectra of $\mathrm{ZnO}: \mathrm{Al}$ thin films.

Table 1: Crystal size $\mathrm{ZnO}: \mathrm{Al}$ thin film with variation post-heating temperatures

\begin{tabular}{cc}
\hline Temperature $\left({ }^{\circ} \mathrm{C}\right)$ & Crystal size $(\mathrm{nm})$ \\
\hline 400 & 16 \\
450 & 21 \\
500 & 39 \\
550 & 41 \\
600 & 34 \\
\hline
\end{tabular}




\subsection{SEM and EDS Analyses of ZnO:Al Thin Film}

Figure 3 shows SEM images of $\mathrm{ZnO}$ :Al. The surface morphology of thin film contains a lot of tiny nanoparticles with homogenous distribution. It can be seen clearly that there is no obvious different of SEM images for different postheating temperatures. The SEM images also exhibit that the grains totally cover the substrate without cracking and have a good interconnection between each particle. The average particle size of nanoparticles annealed at $400^{\circ} \mathrm{C}, 500^{\circ} \mathrm{C}$ and $600^{\circ} \mathrm{C}$ are $38 \pm 7 \mathrm{~nm}, 50 \pm 10 \mathrm{~nm}$ and $66 \pm 12 \mathrm{~nm}$, respectively. Energy disperse spectroscopy (EDS) analysis was further conducted to confirm the success of Al-doped into ZnO. As shown in Figure 3(d), a representative EDS result exhibits the peak of $\mathrm{Al}$ at energy $1.5 \mathrm{KeV}$ with atomic concentration of $0.99 \%$. This analysis confirms that $\mathrm{Al}$ as an extrinsic dopant has been successfully doped into $\mathrm{ZnO}$ structure. The atomic concentrations of zinc $(\mathrm{Zn})$ and oxygen $(\mathrm{O})$ were $47.13 \%$ and $51.88 \%$, respectively.
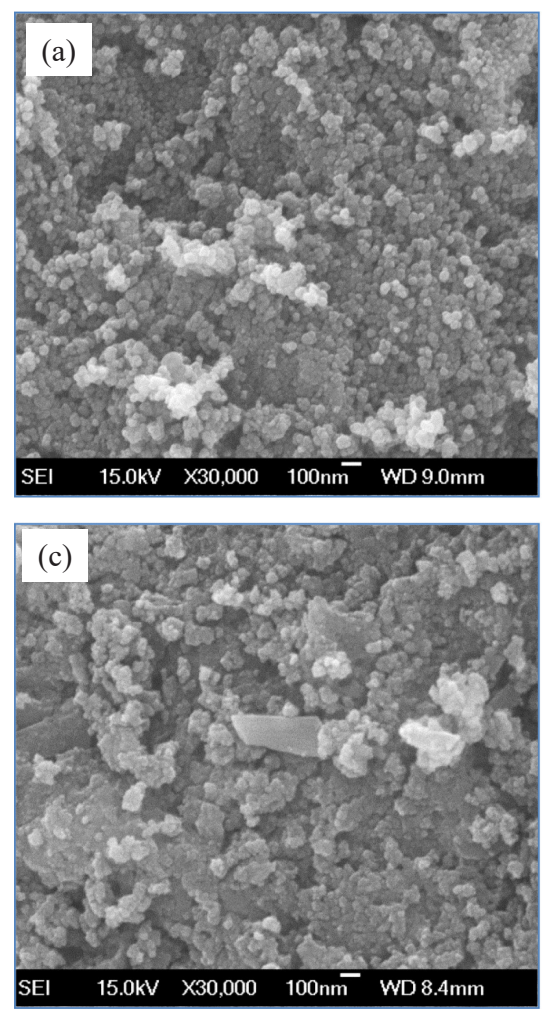

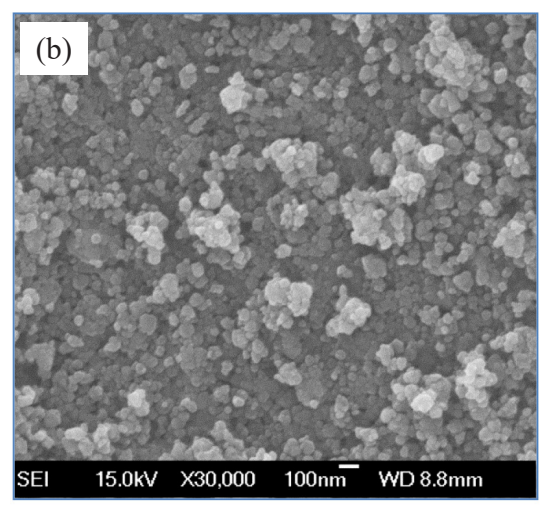

(d)

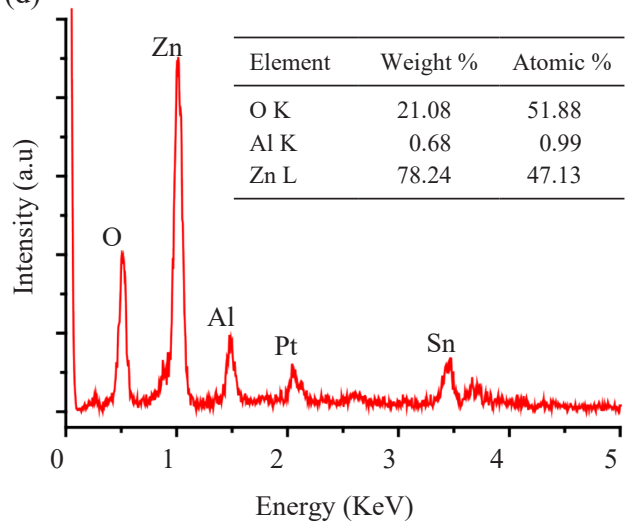

Figure 3: SEM images of $\mathrm{ZnO}$ : $\mathrm{Al}$ thin films at (a) $400^{\circ} \mathrm{C}$, (b) $500^{\circ} \mathrm{C}$, (c) $600^{\circ} \mathrm{C}$ and (d) EDS to show the presence of Al. 


\subsection{Optical Properties of ZnO:Al Thin Films}

Figures 4 and 5 exhibit the transmittance and absorbance spectra, respectively. The transmittance spectrum of the $\mathrm{ZnO}: \mathrm{Al}$ thin films in Figure 4 shows a sharp increase in the transmittance value for all samples that occurs in the wavelength range of approximately $350 \mathrm{~nm}$ to $400 \mathrm{~nm}$, which is the ultraviolet wavelength region. For $\mathrm{ZnO}: \mathrm{Al}$ thin film samples heated at post-heating temperature, the transmittance value is about $75 \%$ to $80 \%$ at a wavelength of about $600 \mathrm{~nm}$ to $700 \mathrm{~nm}$ and the reduction in heating of $500^{\circ} \mathrm{C}$. The high transmittance value of thin films is good and suitable for solar cell applications. Figure 5 shows the absorbance edges of the samples heated at temperatures of $450^{\circ} \mathrm{C}$ and $550^{\circ} \mathrm{C}$ shift to a shorter wavelength region, while those of samples heated at post-heating temperatures of $500^{\circ} \mathrm{C}$ and $600^{\circ} \mathrm{C}$ shift to a longer wavelength region.

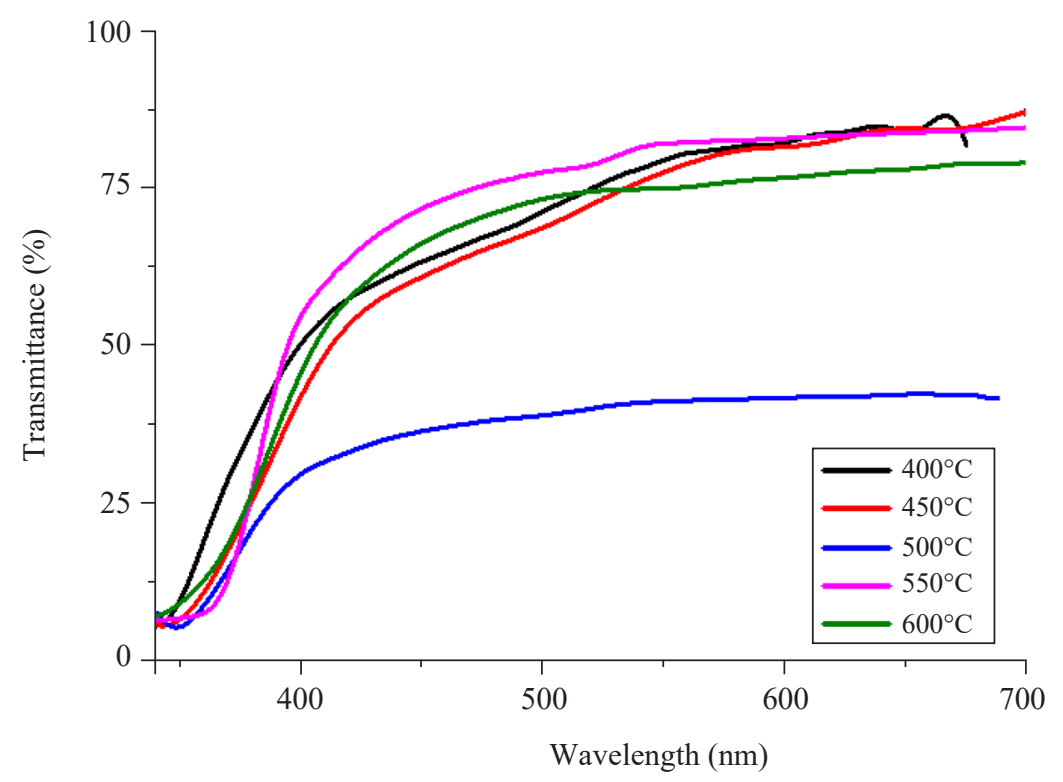

Figure 4: Transmittance spectrum of $\mathrm{ZnO}: \mathrm{Al}$ thin films. 


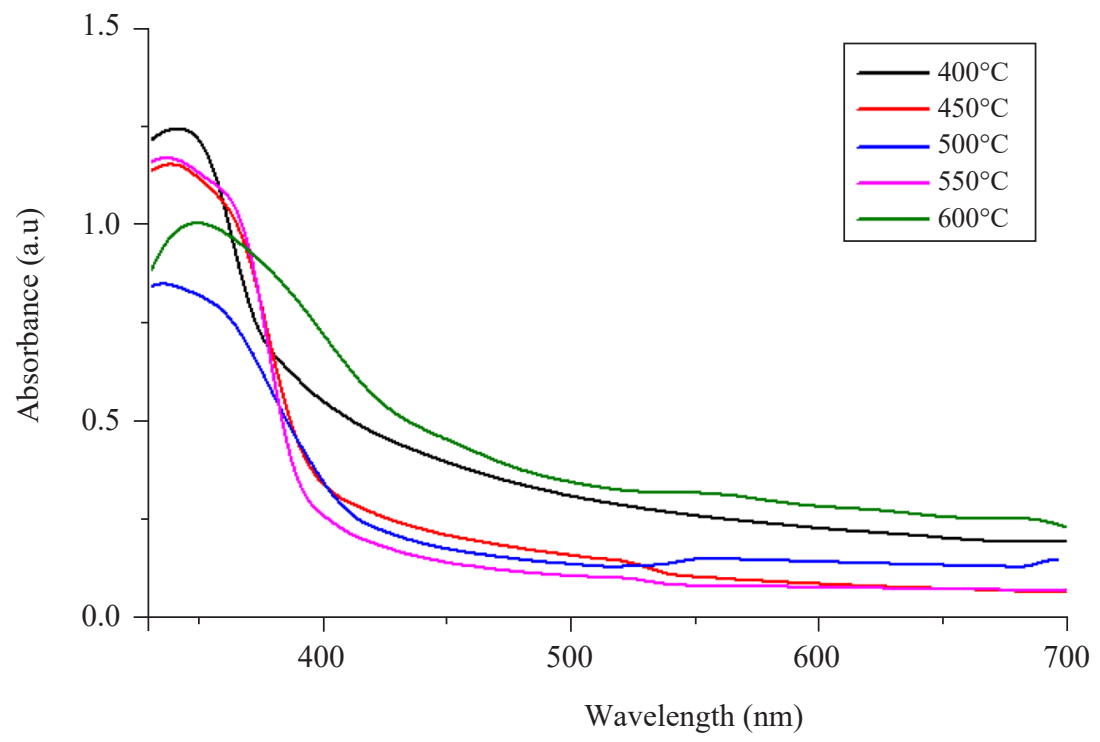

Figure 5: Absorbance spectrum of $\mathrm{ZnO}$ :Al thin films.

The energy bandgap of the $\mathrm{ZnO}: \mathrm{Al}$ thin film is further calculated using Equation $2 .{ }^{26}$

$$
(\alpha h v)^{2}=\mathrm{C}_{\mathrm{D}}\left(h v-\mathrm{E}_{\mathrm{opt}}\right)
$$

Where, $\alpha=$ absorption coefficient, $v=$ frequency, $\mathrm{C}_{\mathrm{D}}=$ proportionality constant, $h=$ Planck's constant and $\mathrm{E}_{\mathrm{opt}}=$ optical bandgap.

Based on the Tauc Plot method in Figure 6, the energy bandgap of the ZnO:Al thin films with variation post-heating temperatures could be obtained. Table 2 lists that the energy bandgap value increases from $3.16 \mathrm{eV}$ to $3.40 \mathrm{eV}$ with increasing the post-heating temperature from $400^{\circ} \mathrm{C}$ to $500^{\circ} \mathrm{C}$. When the post-heating temperature was increased to $550^{\circ} \mathrm{C}$ and $600^{\circ} \mathrm{C}$, the energy bandgap value slightly decreased to $3.20 \mathrm{eV}$. This phenomenon may be related to defects in thin film due to rise of heating temperature. ${ }^{27}$ 


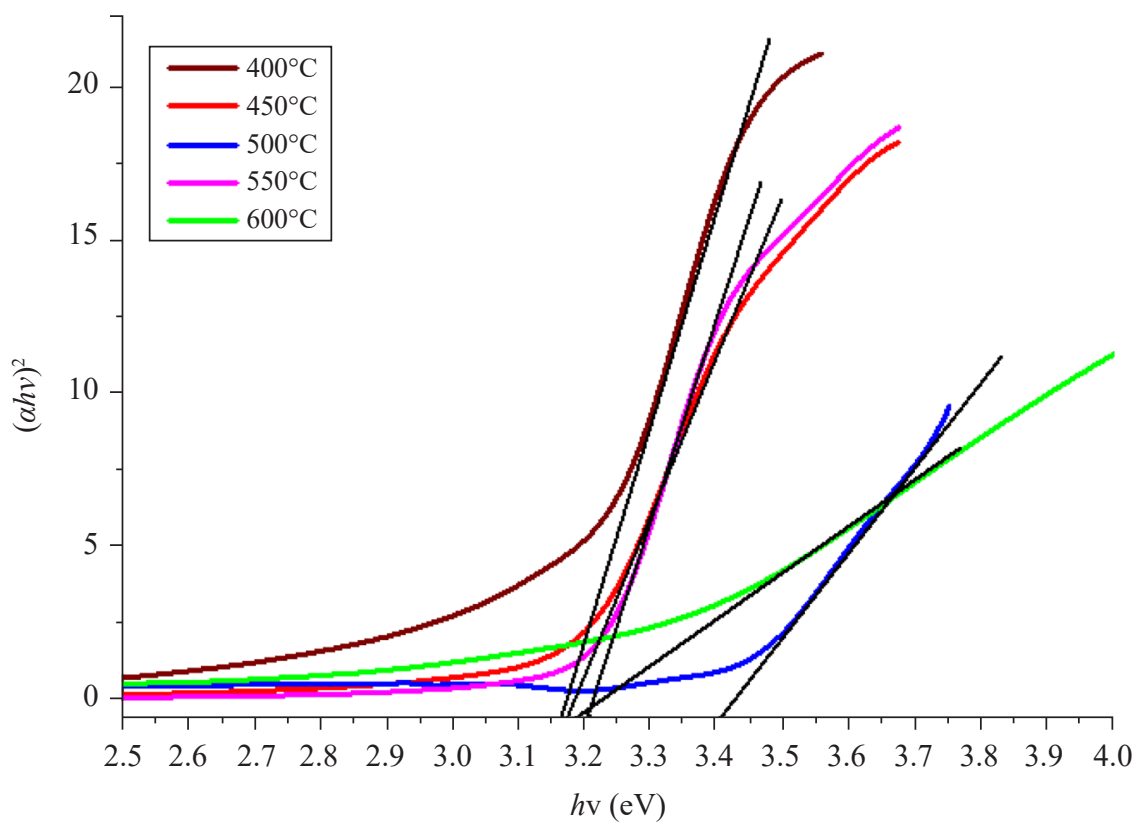

Figure 6: Energy bandgap of $\mathrm{ZnO}$ :Al thin films using Tauc Plot.

Table 2: Energy bandgap of $\mathrm{ZnO}$ :Al thin films.

\begin{tabular}{cc}
\hline Temperature $\left({ }^{\circ} \mathrm{C}\right)$ & Bandgap $(\mathrm{eV})$ \\
\hline 400 & 3.16 \\
450 & 3.17 \\
500 & 3.40 \\
550 & 3.20 \\
600 & 3.20 \\
\hline
\end{tabular}

\subsection{Dye Spectrum of Red Dragon Fruit Extract}

The absorbance spectrum of red dragon fruit solution was tested with UV-vis spectrophotometer. Figure 7 shows that the red dragon fruit dye has the absorbance at UV and visible light range with peak absorbance of $254 \mathrm{~nm}$ and $570 \mathrm{~nm}$, respectively. The result indicates that the extract of red dragon fruit has a great potential to be used as the dye sensitizer for DSSC device. 


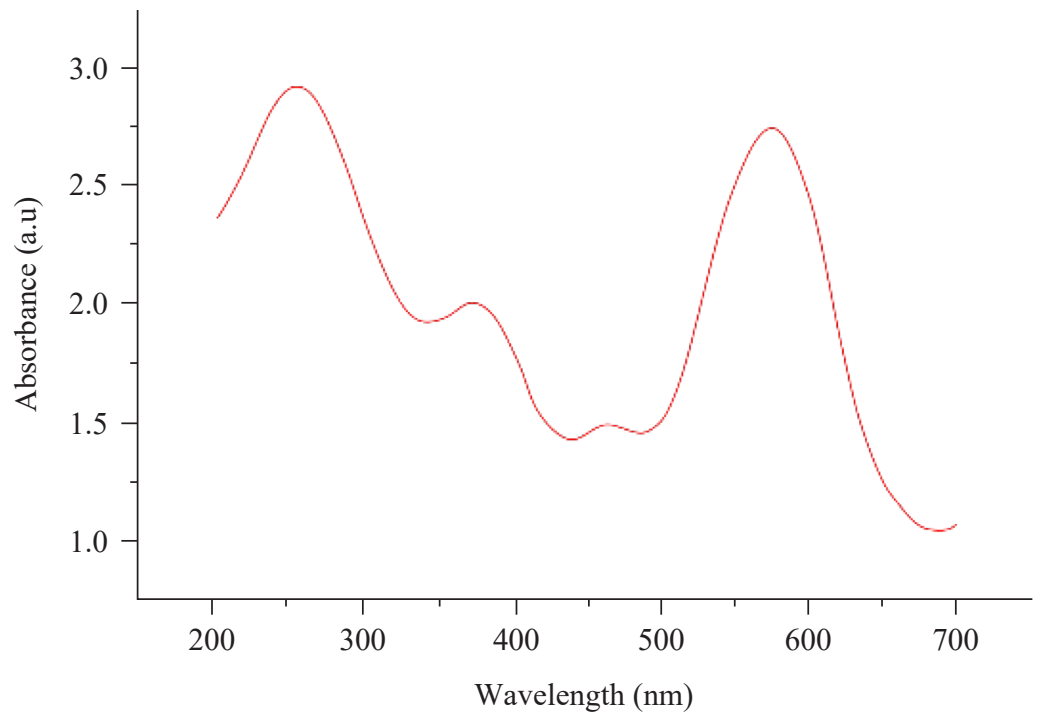

Figure 7: Absorbance of red dragon fruit dye.

\subsection{DSSC Efficiency}

The DSSC efficiency can be obtained by comparing the power produced by the prototype DSSC with the power of light source $\left(\mathrm{P}_{\mathrm{in}}\right)$, as shown in Equations 3 and 4.

$$
\begin{aligned}
& \eta=\frac{\mathrm{P}_{\text {max }}}{\mathrm{P}_{\text {in }}} \times 100 \%=\mathrm{FF} \frac{\mathrm{J}_{\mathrm{SC}} \times \mathrm{V}_{\mathrm{OC}}}{\mathrm{P}_{\text {in }}} \times 100 \% \\
& \mathrm{FF}=\frac{\mathrm{J}_{\max } \times \mathrm{V}_{\text {max }}}{\mathrm{J}_{\mathrm{SC}} \times \mathrm{V}_{\mathrm{OC}}}
\end{aligned}
$$

Where, $\eta=$ DSSC efficiency $(\%), J_{\text {sc }}=$ current density $(\mathrm{mA}), \mathrm{V}_{\mathrm{oc}}=$ voltage $(\mathrm{mV})$, $\mathrm{P}_{\text {in }}=$ input power $(\mathrm{mW})$ and $\mathrm{FF}=$ fill factor.

As listed in Table 3, the efficiency of DSSC increases with the rise of postheating temperature. The maximum efficiency is $0.398 \%$ at a temperature of $600^{\circ} \mathrm{C}$. The reasons for this could be explained: first, a better crystallinity as proved by XRD analysis; and second, the absorption spectra in Figure 5 exhibits that $\mathrm{ZnO}: \mathrm{Al}$ with annealing temperature of $600^{\circ} \mathrm{C}$ had the highest absorption in the visible light region among other temperatures. To further investigate the higher efficiency with a higher temperature, the electrochemical impedance spectra (EIS) analysis was conducted in electrolyte solution of potassium 
chloride $(\mathrm{KCl}, 1 \mathrm{M})$. The EIS data can be used to evaluate the charge transfer property by comparing the diameter of that semicircle in Figure 8 . The charge transfer resistance $\left(\mathrm{R}_{\mathrm{ct}}\right)$ could be determined after fitting technique. The value of $\mathrm{R}_{\mathrm{ct}}$ for heating at $600^{\circ} \mathrm{C}$ is $6.5 \mathrm{k} \Omega$, which is lower than at $500^{\circ} \mathrm{C}(7.6 \mathrm{k} \Omega)$ or $400^{\circ} \mathrm{C}(9.5 \mathrm{k} \Omega)$. Therefore, the other reason for maximum efficiency at $600^{\circ} \mathrm{C}$ post-heating temperature is due to its lowest resistance that leading to most efficient charge transfer. We realised that presence efficiency is still relatively low but there is always room for improvement. Therefore, further research and development is needed to conduct in the future.

Table 3: Values of voltage, current density, power, fill factor and efficiency of DSSC.

\begin{tabular}{cccccc}
\hline Temperature $\left({ }^{\circ} \mathrm{C}\right)$ & $\mathrm{V}_{\mathrm{oc}}(\mathrm{V})$ & $\mathrm{J}_{\mathrm{sc}}\left(\mathrm{mA} / \mathrm{cm}^{2}\right)$ & $\mathrm{P}_{\max }\left(\mathrm{W} / \mathrm{cm}^{2}\right)$ & $\mathrm{FF}(\%)$ & $\eta(\%)$ \\
\hline 400 & 0.45 & 0.350 & 0.031 & 19.644 & 0.084 \\
450 & 0.45 & 0.450 & 0.052 & 25.925 & 0.143 \\
500 & 0.45 & 0.487 & 0.068 & 31.339 & 0.188 \\
550 & 0.50 & 0.650 & 0.094 & 28.941 & 0.257 \\
600 & 0.55 & 1.168 & 0.250 & 22.605 & 0.398 \\
\hline
\end{tabular}

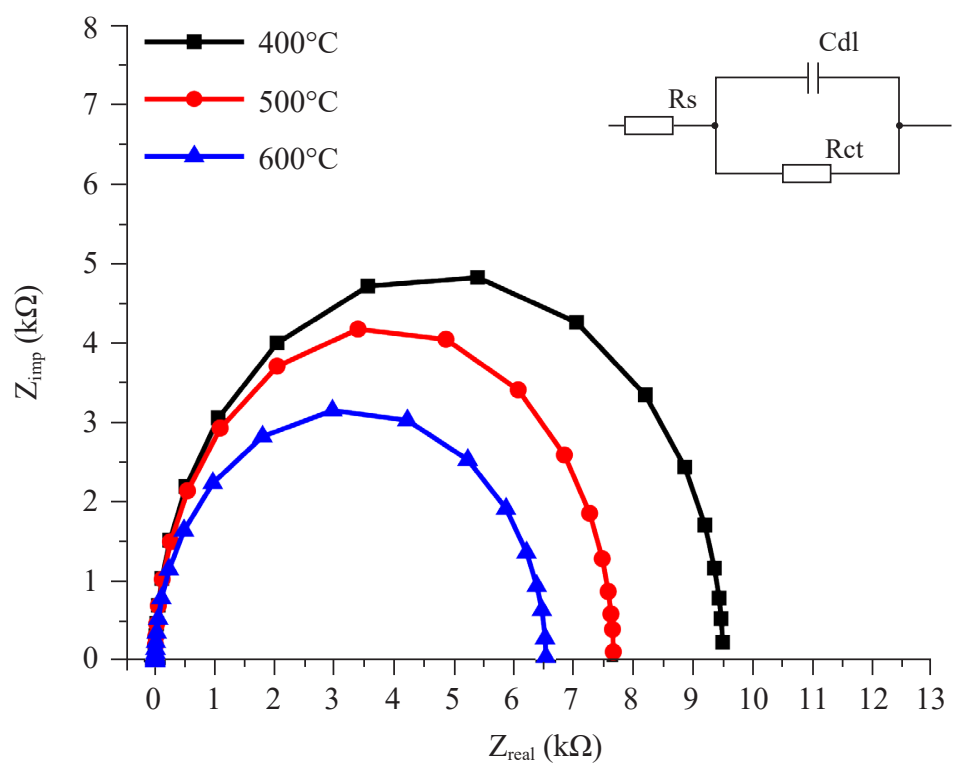

Figure 8: EIS of $\mathrm{ZnO}$ :Al thin films. 


\section{CONCLUSION}

The DSSC prototype has been successfully fabricated using ZnO:Al thin film and dye from red dragon fruit extract as working electrodes. The XRD analysis confirmed that all samples had the hexagonal wurtzite structure. The bandgap values of thin films were about of $3.16 \mathrm{eV}$ to $3.40 \mathrm{eV}$. The surface morphology of $\mathrm{ZnO}: \mathrm{Al}$ thin films was nanoparticle with particle size less than $100 \mathrm{~nm}$. We found that the efficiency of DSCC gradually improved with increasing the post-heating temperature. $\mathrm{ZnO}: \mathrm{Al}$ with post-heating temperature of $600^{\circ} \mathrm{C}$ had the highest efficiency of $0.398 \%$. The optimum efficiency was contributed by the better crystallinity, more efficient charge transfer and higher absorption properties.

\section{ACKNOWLEDGEMENTS}

This work was supported by the Indonesia Directorate of Research and Community Service (No. 027/UN33.8/LL/2018).

\section{REFERENCES}

1. Grätzel, M. (1998). Demonstrating electron transfer and nanotechnology: A natural dye-sensitized nanocrystalline energy converter. J. Chem. Educ., 75(6), 752. https://doi.org/10.1021/ed075p752

2. Vittal, R. \& Ho, C. K. (2017). Zinc oxide based dye-sensitized solar cells: A review. Renew. Sustain. Energy Rev., 70, 920-935. https://doi.org/10.1016/j.rser .2016 .11 .273

3. Siregar, N., Motlan \& Panggabean, J. H. (2020). The effect magnesium (Mg) on structural and optical properties of $\mathrm{ZnO}: \mathrm{Mg}$ thin film by sol-gel spin coating method. J. Phys. Conf. Ser., 1428(012026). https://doi.org/10.1088/1742-6596/ $1428 / 1 / 012026$

4. Zhai, C.-H. et al. (2016). Effects of $\mathrm{Al}$ doping on the properties of $\mathrm{ZnO}$ thin films deposited by atomic layer deposition. Nanoscale Res. Lett., 11, 407. https://doi.org/10.1186/s11671-016-1625-0

5. Tumbul, A. et al. (2018). Solution processed boron doped $\mathrm{ZnO}$ thin films: Influence of different boron complexes. Mater. Res. Express, 6(3), 035903. https://doi.org/ 10.1088/2053-1591/aaf4d8

6. Amara, S. \& Bouafia, M. (2015). Investigation on optical, structural and electrical properties of annealed AZO/Al/AZO multilayer structures deposited by dc magnetron sputtering. J. Mater. Sci. Mater. Electron., 26(3), 1763-1769. https://doi.org/10.1007/s10854-014-2605-8

7. Opel, M. et al., (2013). Laser molecular beam epitaxy of $\mathrm{ZnO}$ thin films and heterostructures. J. Phys. D: Appl. Phys., 47(3), 034002. https://doi.org/ 10.1088/0022-3727/47/3/034002 
8. Dave, P. Y. et al. (2016). Examination of zinc oxide films prepared by magnetron sputtering. Procedia Tech., 23, 328-335. https://oi.org/10.1016/ j.protcy.2016.03.034

9. Wang, Z. et al. (2019). Vacancy cluster in $\mathrm{ZnO}$ films grown by pulsed laser deposition. Sci. Rep., 9, 3534. https://doi.org/10.1038/s41598-019-40029-3

10. Cho, J. et al. (2019). Transparent $\mathrm{ZnO}$ thin-film deposition by spray pyrolysis for high-performance metal-oxide field-effect transistors. Materials, 12(20), 3423. https://doi.org/10.3390/ma12203423

11. Jouya, M., Taromian, F. \& Siami, S. (2017). Rapid growth of zinc oxide nanobars in presence of electric field by physical vapor deposition. J. Theor. Appl. Phys., 11, 291-299. https://doi.org/10.1007/s40094-017-0270-z

12. Yadav, A. B., Pandey, A. \& Jit, S. (2014). Effects of annealing temperature on the structural, optical, and electrical properties of $\mathrm{ZnO}$ thin films grown on n-Si $\langle 100\rangle$ substrates by the sol-gel spin coating method. Acta. Metall. Sin. (English Lett.), 27, 682-688. https://doi.org/10.1007/s40195-014-0097-4

13. Hosseinnejad, M. T. et al. (2016). Preparation of nanostructured $\mathrm{ZnO}$ thin films using magnetron sputtering for the gas sensors applications. J. Inorg. Organomet. Polym., 26, 405-412. https://doi.org/10.1007/s10904-015-0324-0

14. Islam, M. R. et al. (2019). Structural, optical and photocatalysis properties of sol-gel deposited Al-doped ZnO thin films. Surf. and Interfaces, 16, 120-126. https://doi.org/10.1016/j.surfin.2019.05.007

15. Chen, W.-J. et al. (2012). Synthesis of $\mathrm{ZnO}: \mathrm{Al}$ transparent conductive thin films using sol-gel method. Procedia Eng., 36, 54-61. https://doi.org/10.1016/j. proeng.2012.03.010

16. Chou, J.-C. et al. (2019). Dye-sensitized solar cells using aluminum-doped zinc oxide/titanium dioxide photoanodes in parallel. Energies, 12(18), 3469. https://doi.org/10.3390/en12183469

17. Pandey, P. et al. (2017). Effects of annealing temperature optimization on the efficiency of $\mathrm{ZnO}$ nanoparticles photoanode based dye sensitized solar cells. J Mater Sci: Mater Electron, 28, 1537-1545. https://doi.org/10.1007/s10854 -016-5693-9

18. Bekele, E.T. et al. (2021). Biotemplated synthesis of titanium oxide nanoparticles in the presence of root extract of Kniphofia schemperi and its application for dye sensitized solar cells. Int. J. Photoenergy, 2021, 6648325. https://doi.org/ $10.1155 / 2021 / 6648325$

19. Siregar, N., Motlan \& Panggabean, J. (2020). The effect magnesium (Mg) on structural and optical properties of $\mathrm{ZnO}: \mathrm{Mg}$ thin film by sol-gel spin coating method. J. Phys. Conf. Ser., 1428, 012026. https://doi.org/10.1088/1742-6596/ 1428/1/012026

20. Kumar, R., Sahajwalla, V. \& Bhargava, P. (2019). Fabrication of a counter electrode for dye-sensitized solar cells (DSSCs) using a carbon material produced with the organic ligand 2-methyl-8-hydroxyquinolinol (Mq). Nanoscale Adv., 1(8), 3192-3199. https://doi.org/10.1039/C9NA00206E 
21. Motlan \& Siregar, N. (2018). The effect of post-heating temperature on of the eficency of dye sensitized solar cell (DSSC) with using $\mathrm{ZnO}$ thin film and dye from Dutch eggplant fruit (Solanum betaceum). J. Phys. Conf. Ser., 1120, 012082. https:// /doi.org/10.1088/1742-6596/1120/1/012082

22. Gultom, N. S., Abdullah, H. \& Kuo, D.-H. (2020). Phase transformation of bimetal zinc nickel oxide to oxysulfide photocatalyst with its exceptional performance to evolve hydrogen. Appl. Catal. B., 272, 118985. https://doi.org/10.1016/ j.apcatb.2020.118985

23. Gultom, N. S., Abdullah, H. \& Kuo, D.-H. (2019). Facile synthesis of cobalt-doped $(\mathrm{Zn}, \mathrm{Ni})(\mathrm{O}, \mathrm{S})$ as an efficient photocatalyst for hydrogen production. J. Energy Inst., 92(5),1428-1439. https://doi.org/10.1016/j.joei.2018.08.008

24. Mohammadi, M., Roknabadi, M. R. \& Arabshahi, H. (2010). Investigations on impact of post-heat temperatures, optical and electrical properties of Al-doped $\mathrm{ZnO}$ thin films prepared by sol-gel method. Indian J. Sci. Technol., 3(2), 110-112. https://doi.org/10.17485/ijst/2010/v3i2/29659

25. Darvishi Kamachali, R. (2020). A model for grain boundary thermodynamics. RSC Adv., 10(45), 26728-26741. https://doi.org/10.1039/D0RA04682E

26. Abdullah, H. et al. (2020). Effects of tin in La-Sn-Codoped $\mathrm{Zn}(\mathrm{O}, \mathrm{S})$ photocatalyst to strongly cleave the Azo bond in Azobenzene with in situ generated hydrogen. ACS ACS Appl. Mater. Interfaces., 12(14), 16186-16199. https://doi.org/10.1021/ acsami.9b19885

27. Sengupta, J., Ahmed, A. \& Labar, R. (2013). Structural and optical properties of post annealed $\mathrm{Mg}$ doped $\mathrm{ZnO}$ thin films deposited by the sol-gel method. Mater. Lett., 109, 265-268, https://doi.org/10.1016/j.matlet.2013.07.104 